\title{
Genes and Genetics of Tuberculosis
}

\author{
Bhaswati Pandit* \\ National Institute of Biomedical Genomics, India
}

Submission: March 03, 2017; Published: May 05, 2017

*Corresponding author: Bhaswati Pandit, National Institute of Biomedical Genomics, PO: NSS, Kalyani, Nadia 741251, West Bengal, India, Tel: 91-033 25612959; Fax: 91-033 25612959, Email: bp1@nibmg.ac.in

\begin{abstract}
Tuberculosis affects human life globally for long time. About one third of the world's population is infected with the causal pathogen Mycobacterium tuberculosis but without presenting any clinical symptoms. The difference in clinical outcome of infection suggests that host genetic makeup is responsible for such variability. Attempts have been made to identify the underlying genes. In case of Mendelian susceptibility to mycobacterial disease (MSMD) a rare disease with immune-deficiency, mutations were identified in genes that impair IFN $\gamma$ signaling pathway. Linkage studies have identified several loci but exact gene was never pinpointed. Candidate gene association studies carried out in different populations, identified several risk alleles. But findings of all these studies were hardly replicated in another population. Findings are also not justifiable in some cases because of limited sample size. GWAS also identified several susceptible locus, many of which were replicated in another population where as many were not. Gene expression analysis also adds onto identification of gene implicated in infection and thus enhances knowledge on genes playing significant role in mycobacterium infection. However all these studies show that not a single gene but many genes are orchestrated together in determining the fate of infection. More research is necessary to find out such genes, their interaction with other members and complicated network formed.
\end{abstract}

Keywords: Tuberculosis; Susceptibility; Genes; mutations; DNA variants

Abbreviations: GWAS: Genome Wide Association Study; MSMD: Mendelian Susceptibility to Mycobacterial Disease; TB: Tuberculosis

\section{Introduction}

Tuberculosis (TB) is a deadly disease afflicting human kind from long time. Pre historic evidence found in excavation [1], mummies [2] etc. suggest that tuberculosis was present in ancient days. The disease is caused by infection with Mycobacterium tuberculosis which is transmitted from an infected person in form of aerosol droplets. WHO estimates 10.4 million new cases in 2015 [3]. There is an estimate of 1.4 million deaths due to TB in the year 2015. The outcome of infection is manifold. Only a minor group of people develop active tuberculosis upon exposure to Mycobacterium tuberculosis. A handful of individuals are able to clear the infection, whereas majority of infected individuals harbor the infection in latent condition.

In latent condition Mycobacterium within macrophages encloses itself in cellular aggregates formed by different kind of immune cells. Such compact cellular aggregates are called granuloma [4]. About one third of the world population belongs to latent infected group. Only $10 \%$ of them may express the disease in one's life time by reactivation of the latent pathogen depending on the immune status of the host. All these observations, lead to the obvious question why such differences exist and what determines such differences? Before discovery of mycobacterium bacilli by Robert Koch, it was thought that tuberculosis has a prominent hereditary component as many members in the same family were affected. However, after Koch's discovery the thought was that Mycobacterium tuberculosis is sole responsible for the disease and elimination of the bacteria will prevent the disease. But it was gradually realized that bacilli alone is not sufficient for an individual to express the disease.

At present, it is unequivocally proved that not only the pathogen but host factors have major contribution in successful establishment of infection. Twin studies and animal models suggest that host factor play considerable role in predisposing an individual to such infections. Concordance of tuberculosis is higher among monozygotic twins than dizygotic twins $[5,6]$. Animals infected with M.tb can result into susceptible and resistant group depending on the genetic background of the animal. All these evidences suggest that host susceptibility is determined by the genetic makeup of an individual which controls immune response. Genetic locus controlling such susceptibility to infection can be identified by screening and comparing infected individuals in a family or community to noninfected individuals [7], by comparing syntenic locus identified 
in animals [8] already demonstrated to have role in infection or genes which has functional implication in immunity [9].

With the aim to identify genes or genetic variants playing role in susceptibility to tuberculosis, initially linkage study and later on case control association studies were undertaken by several groups. Linkage studies are family based, where affected individuals sharing similar phenotypes as well as unaffected members are screened for genetic markers across all chromosomes. Commonality of markers in different regions of chromosomes of the affected members, are compared to

Discussion unaffected members to locate a genetic loci which is significantly linked and co-segregate with the phenotype. The genomic locus identified may harbor the causal gene that contributes to such altered disease phenotype. The case control approach is another approach where instead of family members, unrelated 'case' (active disease) and 'control' (without disease) are enrolled for screening genetic markers. It is then tested whether the genetic variants are associated with the disease trait. Selectively few candidate genes can be tested for the purpose or the test may be extended to the whole genome level.

\section{Mendelian Susceptibility to Mycobacterium Disease (MSMD)}

Table 1: Genes for MSMD and their function.

\begin{tabular}{|c|c|c|c|}
\hline Gene & Other Name & Chromosomal location & Function \\
\hline IFN $\gamma \mathrm{R} 1$ & IFN $\gamma$ receptor subunit 1 & $6 q 23.3$ & Receptor \\
\hline IFN $\gamma R 2$ & IFN $\gamma$ receptor subunit 2 & $21 \mathrm{q} 22.11$ & Receptor \\
\hline IL $12 \mathrm{p} 40$ & p40 subunit of IL12 & $5 q 33.3$ & Cytokine \\
\hline IL12RB1 & IL12 receptor subunit 1 & $19 q 13.11$ & Receptor \\
\hline STAT1 & Transcription factor & $2 \mathrm{q} 32.2$ & Aids IL12 transcription \\
\hline IRF8 & Interferon regulatory factor & $16 \mathrm{q} 24.1$ & Developing IL12 producing Cd1a and Cd11c cells \\
\hline ISG15 & Interferon stimulatory gene & $1 \mathrm{p} 36.33$ & Transcription of IFN $\gamma$ \\
\hline CYBB & NADPH oxidase & Xp21.1-p11.4 & $\begin{array}{l}\text { IFN } \gamma \text { dependent respiratory oxidation in response to } \\
\text { infection }\end{array}$ \\
\hline NEMO & NFk $\beta$ essential modulator & Xq28 & $\begin{array}{c}\text { Activation of NFk } \beta \text { signaling, T cell and induction of } \\
\text { IL12 by CD } 40 \mathrm{~L}\end{array}$ \\
\hline
\end{tabular}

A rare form of tuberculosis known as Mendelian Susceptibility to Mycobacterium Disease (MSMD) is a class of disease where children are immune compromised, displaying severe symptoms of tuberculosis even when infected with weak strain of mycobacterium like BCG or natural atypical strains [10]. The penetrance of the disease is highly variable. Linkage studies with the affected family members led to identification of the region on chromosome 6 harboring the gene IFN $\gamma$ receptor. Sequencing of IFN $\gamma$ receptor 1 gene identified mutations leading to premature termination [11]. Later on mutations were detected in IFN- $\gamma$ R2 gene also [12]. The two subunits combine to form IFN $-\gamma$ receptor, which binds to its ligand IFN $\gamma$ and transduce the signal to downstream effector molecule. Eventually many more mutations were identified in several other genes which include autosomal genes like IRF8, IL12B, IL12RB1, STAT1, ISG15 and X-linked NEMO, CYBB [13] (Table 1). The common thread between these genes is that they all are involved in the circuit of IL12 induced IFN $\gamma$ activation pathway [14]. These mutations lead to recessive or dominant form of disease, with complete or partial loss of function. Mutations in all above mentioned genes explain $50 \%$ of the cases with remaining $50 \%$ cases still unknown for mutations. All these mutations cause inactivation of IFN $\gamma$ or impaired signaling leading to inborn error in immunity. This suggest that IFN $\gamma$ mediated immunity is central to mycobacterial infection.

\section{Linkage studies}

Shaw and his colleagues studied several families in Brazil and identified a TB linked locus presenting weak linkage to CXCR2 gene $(\mathrm{P}=0.039)$ which is tightly linked to SLC11A1 (NRAMP1) gene [15]. This region encompasses SLC11A1 and TNF gene cluster even though neither of them presented any evidence of linkage independently. SLC11A1 was well characterized and known for its variants to be associated with tuberculosis. Hypothesizing that this gene may be a good candidate gene for susceptibility to tuberculosis a linkage study was performed in a large Aboriginal Canadian family. Evidence of linkage was found in SLC11A1 region (2q35) (LOD=3.8) but no mutations were reported [16]. Another outcome of this study was that no significant linkage to HLA region was found which is otherwise thought to have important role in infection. Gambian and South African sib pair analysis identified seven loci, two of which (15q11-q13 LOD 2.00, Xq26 LOD 1.77) were replicated in another independent set. However, all of these linkages were weak $[17,18]$. Further evidence of linkage was obtained at the locus 8q12-13 (LOD>3) in a study performed on 96 Morroccan families [19]. Stein et al reported linkage to 7p22 locus among Ugandan people, which harbors IL6 gene nearby 
[20]. They also reported additional two loci 2q21-24 and 5p13$5 q 22$ associated with phenotype of non reactivity to tuberculin skin test. Evidence of age specific variation was obtained in a study led by Mahasirimongkol et al. [21]. They reported linkage in two regions $17 \mathrm{p} 13.3-13.1,20 \mathrm{p} 13-12.3$ in patients from Thailand, when patients were stratified on the basis of age of onset ( $<25 \mathrm{yr}$ ). Several groups later undertook fine mapping of the regions identified by linkage analysis by typing more dense markers in the region i.e. single nucleotide polymorphisms (SNP). Fine mapping of 17q11-17 revealed, presence of many genes like NOS2A, CCL2/MCP-1, CCL3/MIP-1a, CCL4/MIP-1b, CCL5/RANTES, CCR7, STAT3 and STAT5A/5B in the region [22]. Screening of this region showed evidence of linkage with LOD score of 2.48 (p 0.0004). Similarly, fine mapping of region 5q31 which spans Th2 cytokine gene cluster revealed association of haplotypes with tuberculosis [23]. Failure to replicate the identified loci in other populations, has dampened the findings of linkage study. This also suggests that not a single gene but multiple genes determine susceptibility to tuberculosis.

\section{Candidate gene association studies}

More than three hundred reports describe association of tuberculosis with DNA variants in more than hundred candidate genes. Candidates are chosen based on their role in immunity. Highly reported and well studied few genes are SLC11A1, VDR, TLRs, HLA class II molecules, IFN $\gamma$, IL10, TNF $\alpha$ [9]. The most successful and convincing study is with SLC11A1 gene which has been replicated in several countries. Studies on mouse model identified and mapped a locus on chromosome1 controlling infection towards mycobacterium, salmonella, and leishmania. The identified gene was called Bcg and later renamed as Nramp1 (natural resistance associated macrophage protein, also known as Solute Carrier Family 11a member1 SLC11A1). The human homologue of Nramp1 was identified and mapped to chromosome 2q35. NRAMP1 is a metal transporter localized in late endosome of macrophages and recruited to phagosome when phagocytosis occurs. Evidence of significant linkage to NRAMP1 or SLC11A1 was demonstrated in a large indigenous Canadian family [16]. The four variants of SLC11A1 gene INT4, D543, 3'UTR, 5'GT as risk allele for TB have been studied in several populations across the globe [24]. Effect of each of the variant is highly variable among different population [25]. Some variants of SLC11A1 not only represent high degree of susceptibility to tuberculosis, but also severe form of it $[25,26,27]$. Meta analysis suggests that variants in SLC11A1 are significantly associated with Asian and Africans with PTB but not among people of European origin [28]. The genetic variants of SLC11A1 are strongly associated (OR 1.75(CI 1.10-2.77), p=0.01) with tuberculosis susceptibility among children [29].

Vitamin D level inversely correlates with severity of TB [30]. It is well established that Vitamin D plays role in defense against mycobacterium by inducing antimicrobial peptide cathelicidine, an inducer of autophagy in macropahage and boosting adaptive immunity. Vitamin D also modulates differentiation and growth of different immune cells. All these cells express vitamin D receptor through which Vitamin D acts. High doses of Vitamin D along with normal course of drugs are used for tuberculosis treatment. Four well known DNA variants in Vitamin D receptor (VDR) gene are studied among different population. They are designated as Fok1 (rs10735810), BsmI (rs154410), Apa I (rs7975232), TaqI (rs731236) depending on the ability of the restriction enzymes to cut at the specific locations. The FokI site has a C/T polymorphisms which determine the amount of VDR produced and contributes to risk for tuberculosis (OR = $1.507,95 \% \mathrm{CI}=1.192-1.906, \mathrm{P}=0.001$ ). Meta-analysis suggests that the roles of other polymorphisms are not significant with development of pulmonary tuberculosis [31] among East Asians. These polymorphic sites are located in the 3'UTR and may have a role in VDR mRNA stability. The results with VDR polymorphisms are also inconsistent among different population. Few studies including the study by Lombard et al did not reveal any association of tuberculosis with VDR polymorphisms, but the F-b-A-T haplotype was observed as a protective factor for TB in South Africa [32]. Other haplotypes f-T-B and f-T-B as risk for tuberculosis were reported in Iranian population [33].

A study on Indians from northern part reported association of HLA-DR2 to susceptibility to tuberculosis [34]. Although no association or linkage was detected in population from south India [35]. Association of HLA DQ alleles are reported in Cambodia [36]. Among Iranian patients HLA-DRB1*07 and HLA-DQA1*0101(OR 2.7, 95\%CI 1.19-6.13, P=0.025 and OR $2.66,95 \%$ CI $1.15-6.44, \mathrm{P}=0.04$, respectively) appeared to be the predisposing alleles and HLA-DQA1*0301 and 0501 the protective alleles (OR 0.254, 95\%CI 0.075-0.865, $\mathrm{P}=0.033$ and OR 0.53, 95\%CI 0.3-0.95, P $=0.045$, respectively) [37]. Associations of different alleles to susceptibility and protection have been reported in South Africa, Greece, Poland, and China. Analysis of (HLA)-DRB1 and -DQB1 gene polymorphisms among Koreans suggest that DRB $1 * 0803(\mathrm{OR}=1.97, \mathrm{p}=0.012)$ and DQB1 $* 601$ (OR $=2.07, \mathrm{p}=0.005, \mathrm{p}(\mathrm{c})>0.05)$ alleles are associated with progression of tuberculosis to severe form and development of drug resistance [38]. A study led by Salei M attempted to correlate HLA class I polymorphism of the host with the strain of M.tb infected [39]. Further they have shown that presence of HLA-B27 allele protect an individual from another episode (OR=0.21 $\mathrm{p}=0.006)$ of disease. More recently a metaanalysis including 31 study suggests that the HLA-DRB1*04, ${ }^{*} 09$, $* 10, * 15$, and $* 16$ gene polymorphisms [ ${ }^{*} 04$ (OR $1.22,95 \%$ CI 1.00-1.48, P = 0.048), *09 (OR 1.50, 95\% CI 1.08-2.08, P = 0.016), *10 (OR 1.23, 95\% CI 1.01-1.49, P = 0.035), *15 (OR 1.40, 95\% CI 1.14-1.73, $\mathrm{P}=0.001$ ), and $* 16$ (OR $1.33,95 \%$ CI 1.08-1.63, P $=0.007)]$ may be associated with risk of TB, particularly among the East Asian. But the HLA-DRB1*11 gene polymorphism *11 (OR 0.72, 95\% CI 0.53-0.99, $\mathrm{P}=0.044$ ), may have protective role. No significant association between the HLA-DRB1*01, *03, *07, $* 08, * 12, * 13$, and $* 14$ gene polymorphisms and TB risk was found [40]. 
Toll like receptor (TLR) play important role in activation of innate immunity against mycobacterial infection. Pathogen associated molecular patterns (PAMP) are recognized by TLRs. These receptors are present on cell surface or intracellularly in cytoplasm or on endosomal membranes. TLR2 and TLR4 form heterodimer with TLR1 or TLR6 and recognize mycobacterial components. Polymorphisms in TLR genes are extensively studied to test association with tuberculosis susceptibility in different ethnicities, but results are contradictory. rs 4833095 in TLR1 gene is associated with resistance to tuberculosis. Metaanalysis suggest that heterozygous individuals with AG genotypes are protected than GG (AG vs. GG: OR=0.77,95\% CI=0.65-0.95, $\mathrm{p}=0.0031$ ) [41]. On meta-analysis rs5743708 turned out to be non significant, even though individual studies report A allele as a risk allele for Hispanic and Asian population. Analysis of another SNP in TLR2 gene (rs3804100) demonstrated that CC genotype is risk for developing tuberculosis. Variants in TLR4 (rs4986791), TLR6 (rs5743810), TLR9 (rs352139) turn out to be risk or protective when studied individually, but overall do not pose any strong effect on risk for TB development.

The candidate association studies performed on different populations are highly heterogeneous in nature. In many studies it is reflected that age should be given importance and age turned out to be an important factor. The variable results of association may be due to genetic heterogeneity, clinical heterogeneity and different LD pattern in different population and limited sample size in each study.

\section{Genome wide association studies (GWAS)}

The aim of Genome wide association study is to identify disease associated DNA variants in a genome wide manner in a large number of samples. Cases with disease and controls without disease are compared in GWAS with appropriate precautionary measurements. The first GWAS for tuberculosis done on African population from Ghana and Gambia, identified an intergenic SNP rs 4331426 (OR 1.19 (1.12-1.26), p=6.8X10-9) on the chromosomal region 18q11.2 [42]. However the biological implication of this SNPS was not known as it is located in the gene desert region. The same tested in Chinese population was significant but with opposite effect $(\mathrm{p}=0.011$, OR $0.62(0.44$ 0.87 ) i.e. protective as reported by Wang et.al. [43]. This locus also failed to replicate in South African Colored population [44]. Another study on Ghana and Gambian population identified another non coding SNP rs 2057178 (OR 0.77 (0.71-0.84), $\mathrm{p}=2.63 \mathrm{X} 10^{-9}$ ) which was associated with resistance to TB [45]. The nearest genes WT1 and RCN1 were located $45 \mathrm{~Kb}$ and 500 $\mathrm{Kb}$ respectively both of which apparently have no connection with infection. However association of this SNP was validated in Russian ( $p=2.0 \times 10^{-2}$, OR 0.91, (0.82-0.99), Indonesian ( $\mathrm{p}=$ $9.9 \times 10^{-2}$, OR 0.84, (0.68-1.03), African Colored population $(\mathrm{p}=$ 2.71X $10^{-6}$, OR $0.62(0.5-0.75)$ [44] also. Since then few more studies across different countries and population have identified some more locus.
A GWAS performed on Russian identified several significant SNPs at the locus $8 \mathrm{q} 24$. The most significant variant rs 4733781 ( $\mathrm{p}=2.6 \mathrm{X} 10^{-11}$ OR $0.84(0.8-0.88)$, is located in an intron of ASAP1 gene. It was demonstrated that this variant can alter ASAP1 expression in dendritic cell affecting its migration [46]. Significant association of rs 4733781 also hold true for African population from Ghana and Gambia, but not in Western Chinese Han and Tibetan population [47]. However the Russian population did not show any association with the SNP at the locus 18q11 previously reported in African population. Another interesting observation was that the significant SNPs identified in African population apparently failed to replicate in Thai and Japanese population. An earlier study on Thai population presented evidence of linkage on 20q12. But only when the patients were stratified based on their age (cut off of 45yr), the young tuberculosis patients presented significant association with SNP rs 6071980 ( $\mathrm{p}=6.69 \times 10^{-8}$ OR 1.94 (1.34-2.82)) on $20 q 12$ [21]. The nearest genes HSPEP1-MAFB are potential candidates for TB susceptibility. Recently, deep sequencing of the region 20q13-12.3 identified rs13830 and rs1127354 in ITPA gene showing association with young (age $<45 \mathrm{yr}$ ) TB patients [48] in Japan. The region 5 q31 harbor a gene cluster of Th2 cytokine and showed evidence of linkage for tuberculosis earlier. Fine mapping of this region among Thai trio families identified DNA variants in three genes SLC22A4, SLC22A5 and KIF3A of nominal significance. However haplotype constructed with three markers from these genes remain significant even after multiple testing corrections [23]. This implies that multiple DNA variants play role in tuberculosis. A separate study on Indonesians identified nine independent locus near genes JAG1, DYNLRB2, EBF1, TMEFF2, CCL17, HAUS6, PENK and TXNDC4. Findings of this study were validated in another Indonesian group as well as among Russian [49] independently or in combination but none of them attained genome wide significance. Previously reported susceptible loci 8q12-13 in a family based discovery study from Morocco was further densely mapped by genotyping SNPS located in the region [19]. Two SNPs rs1568952 and rs2726600 located in introns of TOX gene were significantly associated with tuberculosis (combined $\mathrm{p}=1.1 \times 10^{-5}$ and $9.2 \times 10^{-5}$ ). The association was even stronger in patients with age less than 25 yr. TOX is required for the development of the CD4 T lineage. Results were replicated in Madagascar nuclear families with early onset of TB [50].

A comparative study was performed in a cohort consisting of people from Uganda and Tanzania, consisting of HIV coinfected TB patients and only HIV infected individual who do not develop tuberculosis infection in spite of close exposure to TB patients [51]. A SNP rs4021437 at 5q33.3 was significantly associated with TB infected individuals (OR 0.37, $\mathrm{p}=2.11 \times 10^{-8}$ ) in a HIV positive background. This SNP is located near IL12 gene and embedded in H3K27Ac his tone mark possibly indicating its role in regulation. This again strengthens the fact that IL12 has important role in TB infection. Summary of GWAS done are given in Table 2. 


\section{International Journal of Pulmonary \& Respiratory Sciences}

Table 2: Tuberculosis susceptible loci identified by GWAS. Findings from one study replicated in another population are shown in bold.

\begin{tabular}{|c|c|c|c|c|c|c|c|c|}
\hline Author & SNP & Locus & Location & $\begin{array}{c}\text { Gene } \\
\text { (nearest } \\
\text { gene) }\end{array}$ & Population & OR $(95 \% \mathrm{CI})$ & $p$ value & Replication \\
\hline Thye et.al [42] & rs4331426 & $18 \mathrm{q} 11.2$ & intergenic & $\begin{array}{l}\text { (CTAGE1, } \\
\text { RBBP8) }\end{array}$ & Ghana Gambia & $\begin{array}{c}1.19(1.12- \\
1.26)\end{array}$ & $6.8 \times 10^{-9}$ & $\begin{array}{c}\text { South African, } \\
\text { China, Russia, } \\
\text { Asia, Iran, } \\
\text { Han Taiwan } \\
\text { female }\end{array}$ \\
\hline Thye et.al [45] & rs2057178 & $11 \mathrm{p} 13$ & intergenic & (WT1) & Gambia Ghana & $\begin{array}{l}0.77(0.71- \\
0.84)\end{array}$ & $2.63 \times 10^{-9}$ & $\begin{array}{c}\text { Morroco, } \\
\text { Indonesia, } \\
\text { Russia, } \\
\text { Admixed } \\
\text { colored SA }\end{array}$ \\
\hline \multirow[t]{2}{*}{ Curtis et.al. [46] } & rs4733781 & $8 \mathrm{q} 24$ & Intron & ASAP1 & Russia & $\begin{array}{l}0.84(0.80- \\
0.88)\end{array}$ & $2.6 \times 10^{-11}$ & $\begin{array}{c}\text { Ghana, } \\
\text { Gambia, } \\
\text { China, Tibet }\end{array}$ \\
\hline & rs 10956514 & $8 \mathrm{q} 24$ & Intron & ASAP1 & Russia & $\begin{array}{c}0.85(0.81- \\
0.89)\end{array}$ & $1.0 \times 10^{-10}$ & \\
\hline $\begin{array}{c}\text { Mahasirimongkol } \\
{[21]}\end{array}$ & rs 6071980 & $20 \mathrm{q} 12$ & Intergenic & $\begin{array}{l}\text { (HSPEP1- } \\
\text { MAFB) }\end{array}$ & Thailand (age $<45 \mathrm{yr}$ ) & $\begin{array}{c}1.94(1.34- \\
2.82)\end{array}$ & $6.69 \times 10^{-8}$ & \\
\hline \multirow[t]{2}{*}{ Nakauchi [48] } & rs13830 & $20 \mathrm{q} 13-12.3$ & 3'UTR & ITPA & Japan (age $<45 y r$ ) & $1.5(1.13-1.99)$ & $4.4 \times 10^{-3}$ & \\
\hline & rs1127354 & $20 q 13-12.3$ & Exon & ITPA & Japan (age<45yr) & $1.4(1.07-1.87)$ & $1.5 \times 10^{-2}$ & \\
\hline \multirow[t]{2}{*}{ Grant et. $\mathrm{Al}[50]$} & rs1568952 & $8 q 12-13$ & 3'UTR & TOX & Morocco(age $<25 y r)$ & $\begin{array}{c}3.09(1.99- \\
4.78)\end{array}$ & $4.4 \times 10^{-8}$ & Madagasgar \\
\hline & rs2726600 & $8 q 12-13$ & Intron & TOX & Morocco(age <25yr) & $\begin{array}{l}2.19(1.52- \\
3.14)\end{array}$ & $3.2 \times 10^{-5}$ & \\
\hline Sobata et.al [51] & rs4021437 & $5 q 33.3$ & Intergenic & (IL12) & Uganda, Tanzania & $\begin{array}{c}0.37(0.266- \\
0.528)\end{array}$ & $2.11 \times 10^{-8}$ & \\
\hline Grant et. $\mathrm{Al}[50]$ & rs916943, & $7 \mathrm{p} 21$ & Intron & AGMO & Morocco(age $<25 \mathrm{yr})$ & $\begin{array}{c}2.73(1.78- \\
4.18)\end{array}$ & $2 \times 10^{-6}$ & \\
\hline
\end{tabular}

\section{Host response and activation of genes}

Host response to infection is reflected in its transcriptional signature. Altered gene expression also provide clue for identifying host genes implicated in infectious disease. In case of tuberculosis host gene expression profile has been studied using whole blood or PBMC or different immune cells [52,53,54]. Many of these studies have concluded similar type of genes altered in tuberculosis infection and can discriminate active disease or latency or even from any other type of infection. Altered genes are majorly immune regulator, cytokines or receptors or involved in inflammation or apoptosis triggered by pathogen infection [55]. A study involving patients from UK and Africa suggested presence of neutrophil driven interferon signature with active TB cases, which is absent in latent and healthy individuals [53]. This signature was validated in samples from different countries and different assay platforms. This study also demonstrated that there was significant change in transcriptomics after two months of treatment. Two other studies in Africa also demonstrated decline in certain transcripts after administration of drugs [56,57]. Complement genes within this list suggest complement mediated decrease in bacterial load [57]. Different mycobacterium strain can evoke differential immune response. Change in gene expression was monitored in lung epithelial cells after infecting with different strains of mycobacterium [58].
Strain specific signature was visible with overlapping signature as well. Strain specific signature and activation of functional pathways were also observed for two strains. Strain specific signatures are of immense importance to identify strain specific biomarkers and immunotherapy.

\section{Conclusion}

It is clear that host response to any infection is a multistep process. It is a complex interaction between host and pathogen. In order to understand the biology of infection one needs to dissect the complex interaction between the host genes which are activated to protect the host, whereas the pathogen genes counteract the host defense mechanism. Development of modern genomic tools has enabled us to understand the molecular events. HIV infection has aided the spread of tuberculosis and so is diabetes. Even though we have knowledge on association of numerous variants and their role in tuberculosis but many more are yet to be discovered. Also in many cases it is not clear how the hits of GWAS contribute to susceptibility. More studies are required in future for better understanding.

\section{References}

1. Hershkovitz I, Donoghue HD, Minnikin DE, Besra GS, Lee OY, et al. (2008) Detection and molecular characterization of 9,000-year-old Mycobacterium tuberculosis from a Neolithic settlement in the Eastern Mediterranean. PLoS One 3(10): e3426. 
2. Zink AR, Sola C, Reischl U, Grabner W, Rastogi N, et al. (2003) Characterization of Mycobacterium tuberculosis complex DNAs from Egyptian mummies by spoligotyping. J Clin Microbiol 41(1): 359-367.

3. WHO (2016) Global Tuberculosis Report.

4. Ramakrishnan L (2012) Revisiting the role of the granuloma in tuberculosis. Nat Rev Immunol 12(5): 352-366.

5. Comstock GW (1978) Tuberculosis in twins: a re-analysis of the Prophit survey. Am Rev Respir Dis 117(4): 621-624.

6. Simonds B (1957) Twin research in tuberculosis. Eugen Rev 49(1): 2532.

7. Casanova JL, Abel L (2002) Genetic dissection of immunity to mycobacteria: the human model. Annu Rev Immunol 20: 581-620.

8. Vidal SM, Malo D, Vogan K, Skamene E, Gros P (1993) Natural resistance to infection with intracellular parasites: isolation of a candidate for Bcg. Cell 73(3): 469-485.

9. Fol M, Druszczynska M, Wlodarczyk M, Ograczyk E, Rudnicka W (2015) Immune response gene polymorphisms in tuberculosis. Acta Biochim Pol 62(4): 633-640.

10. Cottle LE (2011) Mendelian susceptibility to mycobacterial disease. Clin Genet 79(1): 17-22.

11. Newport MJ, Huxley CM, Huston S, Hawrylowicz CM, Oostra BA, et al. (1996) A mutation in the interferon-gamma-receptor gene and susceptibility to mycobacterial infection. N Engl J Med 335(26): 19411949.

12. Dorman SE, Holland SM (1998) Mutation in the signal-transducing chain of the interferon-gamma receptor and susceptibility to mycobacterial infection. J Clin Invest 101(11): 2364-2369.

13. Boisson-Dupuis S, Bustamante J, El-Baghdadi J, Camcioglu Y, Parvaneh $\mathrm{N}$, et al. (2015) Inherited and acquired immunodeficiencies underlying tuberculosis in childhood. Immunol Rev 264(1): 103-120.

14. Filipe-Santos O, Bustamante J, Chapgier A, Vogt G, de Beaucoudrey L, et al. (2006) Inborn errors of IL-12/23- and IFN-gamma-mediated immunity: molecular, cellular, and clinical features. Semin Immunol 18(6): 347-361.

15. Shaw MA, Collins A, Peacock CS, Miller EN, Black GF, et al. (1997) Evidence that genetic susceptibility to Mycobacterium tuberculosis in a Brazilian population is under oligogenic control: linkage study of the candidate genes NRAMP1 and TNFA. Tuber Lung Dis 78(1): 35-45.

16. Greenwood CM, Fujiwara TM, Boothroyd LJ, Miller MA, Frappier D, et al. (2000) Linkage of tuberculosis to chromosome 2q35 loci, including NRAMP1, in a large aboriginal Canadian family. Am J Hum Genet 67(2): 405-416.

17. Bellamy R, Beyers N, McAdam KP, Ruwende C, Gie R, et al. (2000) Genetic susceptibility to tuberculosis in Africans: a genome-wide scan. Proc Natl Acad Sci U S A 97(14): 8005-8009.

18. Bellamy R (2000) Identifying genetic susceptibility factors for tuberculosis in Africans: a combined approach using a candidate gene study and a genome-wide screen. Clin Sci (Lond) 98: 245-250.

19. Baghdadi JE, Orlova M, Alter A, Ranque B, Chentoufi M, et al. (2006) An autosomal dominant major gene confers predisposition to pulmonary tuberculosis in adults. J Exp Med 203(7): 1679-1684.

20. Stein CM, Zalwango S, Malone LL, Won S, Mayanja-Kizza H, et al. (2008) Genome scan of $\mathrm{M}$. tuberculosis infection and disease in Ugandans. PLoS One 3(12): e4094.

21. Mahasirimongkol S, Yanai H, Mushiroda T, Promphittayarat W, Wattanapokayakit S, et al. (2012) Genome-wide association studies of tuberculosis in Asians identify distinct at-risk locus for young tuberculosis. J Hum Genet 57(6): 363-367.
22. Jamieson SE, Miller EN, Black GF, Peacock CS, Cordell HJ, et al. (2004) Evidence for a cluster of genes on chromosome 17q11-q21 controlling susceptibility to tuberculosis and leprosy in Brazilians. Genes Immun 5(1): 46-57.

23. Ridruechai C, Mahasirimongkol S, Phromjai J, Yanai H, Nishida N, et al. (2010) Association analysis of susceptibility candidate region on chromosome 5q31 for tuberculosis. Genes Immun 11(5): 416-422.

24. Meilang Q, Zhang Y, Zhang J, Zhao Y, Tian C, et al. (2012) Polymorphisms in the SLC11A1 gene and tuberculosis risk: a meta-analysis update. Int J Tuberc Lung Dis 16(4): 437-446.

25. Searle S, Blackwell JM (1999) Evidence for a functional repeat polymorphism in the promoter of the human NRAMP1 gene that correlates with autoimmune versus infectious disease susceptibility. J Med Genet 36(4): 295-299.

26. Bellamy R, Ruwende C, Corrah T, McAdam KP, Whittle HC, et al. (1998) Variations in the NRAMP1 gene and susceptibility to tuberculosis in West Africans. N Engl J Med 338(10): 640-644.

27. Bellamy R (2002) NRAMP1 and susceptibility to tuberculosis. Int J Tuberc Lung Dis 6: 747.

28. Li HT, Zhang TT, Zhou YQ, Huang QH, Huang J (2006) SLC11A1 (formerly NRAMP1) gene polymorphisms and tuberculosis susceptibility: a meta-analysis. Int J Tuberc Lung Dis 10(1): 3-12.

29. Malik S, Abel L, Tooker H, Poon A, Simkin L, et al. (2005) Alleles of the NRAMP1 gene are risk factors for pediatric tuberculosis disease. Proc Natl Acad Sci U S A 102(34): 12183-12188.

30. Nnoaham KE, Clarke A (2008) Low serum vitamin D levels and tuberculosis: a systematic review and meta-analysis. Int J Epidemiol 37(1): 113-119.

31. Lee YH, Song GG (2015) Vitamin D receptor gene FokI, TaqI, BsmI, and ApaI polymorphisms and susceptibility to pulmonary tuberculosis: a meta-analysis. Genet Mol Res 14(3): 9118-9129.

32. Lombard Z, Dalton DL, Venter PA, Williams RC, Bornman L (2006) Association of HLA-DR, -DQ and vitamin D receptor alleles and haplotypes with tuberculosis in the Venda of South Africa. Hum Immunol 67(8): 643-654.

33. Salimi S, Farajian-Mashhadi F, Alavi-Naini R, Talebian G, Narooie-Nejad $\mathrm{M}$ (2015) Association between vitamin D receptor polymorphisms and haplotypes with pulmonary tuberculosis. Biomed Rep 3(2): 189-194.

34. Singh SP, Mehra NK, Dingley HB, Pande JN, Vaidya MC (1983) Human leukocyte antigen (HLA)-linked control of susceptibility to pulmonary tuberculosis and association with HLA-DR types. J Infect Dis 148(4): 676-681.

35. Sanjeevi CB, Narayanan PR, Prabakar R, Charles N, Thomas BE, et al. (1992) No association or linkage with HLA-DR or -DQ genes in south Indians with pulmonary tuberculosis. Tuber Lung Dis 73(5): 280-284.

36. Goldfeld AE, Delgado JC, Thim S, Bozon MV, Uglialoro AM, et al. (1998) Association of an HLA-DQ allele with clinical tuberculosis. JAMA 279(3): 226-228.

37. Amirzargar AA, Yalda A, Hajabolbaghi M, Khosravi F, Jabbari H, et al. (2004) The association of HLA-DRB, DQA1, DQB1 alleles and haplotype frequency in Iranian patients with pulmonary tuberculosis. Int J Tuberc Lung Dis 8(8): 1017-1021.

38. Kim HS, Park MH, Song EY, Park H, Kwon SY, et al. (2005) Association of HLA-DR and HLA-DQ genes with susceptibility to pulmonary tuberculosis in Koreans: preliminary evidence of associations with drug resistance, disease severity, and disease recurrence. Hum Immunol 66(10): 1074-1081.

39. Salie M, van der Merwe L, Moller M, Daya M, van der Spuy GD, et al. Associations between human leukocyte antigen class I variants and 
the Mycobacterium tuberculosis subtypes causing disease. J Infect Dis 209(2): 216-223.

40. Tong X, Chen L, Liu S, Yan Z, Peng S, et al. (2015) Polymorphisms in HLA-DRB1 gene and the risk of tuberculosis: a meta-analysis of 31 studies. Lung 193(2): 309-318.

41. Schurz H, Daya M, Moller M, Hoal EG, Salie M (2015) TLR1, 2, 4, 6 and 9 Variants Associated with Tuberculosis Susceptibility: A Systematic Review and Meta-Analysis. PLoS One 10(10): e0139711.

42. Thye T, Vannberg FO, Wong SH, Owusu-Dabo E, Osei I, et al. (2010) Genome-wide association analyses identifies a susceptibility locus for tuberculosis on chromosome 18q11.2. Nat Genet 42(9): 739-741.

43. Wang X, Tang NL, Leung CC, Kam KM, Yew WW, et al. (2013) Association of polymorphisms in the Chr18q11.2 locus with tuberculosis in Chinese population. Hum Genet 132(6): 691-695.

44. Chimusa ER, Zaitlen N, Daya M, Moller M, van Helden PD, et al. Genomewide association study of ancestry-specific TB risk in the South African Coloured population. Hum Mol Genet 23(3): 796-809.

45. Thye T, Owusu-Dabo E, Vannberg Fo, van Crevel R, Curtis J, et al. (2012) Common variants at $11 \mathrm{p} 13$ are associated with susceptibility to tuberculosis. Nat Genet 44(3): 257-259.

46. Curtis J, Luo Y, Zenner HL, Cuchet-Lourenco D, Wu C, et al. (2015) Susceptibility to tuberculosis is associated with variants in the ASAP1 gene encoding a regulator of dendritic cell migration. Nat Genet 470 : 523-527.

47. Hu X, Peng W, Chen X, Zhao Z, Zhang J, et al. (2016) No Significant Effect of ASAP1 Gene Variants on the Susceptibility to Tuberculosis in Chinese Population. Medicine (Baltimore) 95(21): e3703.

48. Nakauchi A, Wong JH, Mahasirimongkol S, Yanai H, Yuliwulandari R, et al. (2016) Identification of ITPA on chromosome 20 as a susceptibility gene for young-onset tuberculosis. Hum Genome Var 3: 15067.

49. Png E, Alisjahbana B, Sahiratmadja E, Marzuki S, Nelwan R, et al. (2012) A genome wide association study of pulmonary tuberculosis susceptibility in Indonesians. BMC Med Genet 13: 5.
50. Grant AV, El Baghdadi J, Sabri A, El Azbaoui S, Alaoui-Tahiri K, et al. (2013) Age-dependent association between pulmonary tuberculosis and common TOX variants in the 8q12-13 linkage region. Am J Hum Genet 92(3): 407-414.

51. Sobota RS, Stein CM, Kodaman N, Scheinfeldt LB, Maro I, et al. (2016) A Locus at 5q33.3 Confers Resistance to Tuberculosis in Highly Susceptible Individuals. Am J Hum Genet 98(3): 514-524.

52. Maertzdorf J, Repsilber D, Parida SK, Stanley K, Roberts T, et al. (2011) Human gene expression profiles of susceptibility and resistance in tuberculosis. Genes Immun 12(1): 15-22.

53. Berry MP, Graham CM, McNab FW, Xu Z, Bloch SA, et al. (2010) An interferon-inducible neutrophil-driven blood transcriptional signature in human tuberculosis. Nature 466(7309): 973-977.

54. Stern JN, Keskin DB, Romero V, Zuniga J, Encinales L, et al. (2009) Molecular signatures distinguishing active from latent tuberculosis in peripheral blood mononuclear cells, after in vitro antigenic stimulation with purified protein derivative of tuberculin (PPD) or Candida: a preliminary report. Immunol Res 45(1): 1-12.

55. Azad AK, Sadee W, Schlesinger LS (2012) Innate immune gene polymorphisms in tuberculosis. Infect Immun 80(10): 3343-3359.

56. Blooms CI, Graham CM, Berry MP, Wilkinson KA, Oni T, et al. (2012) Detectable changes in the blood transcriptome are present after two weeks of antituberculosis therapy. PLoS One 7(10): e46191.

57. Cliff JM, Lee JS, Constantinou N, Cho JE, Clark TG, et al. (2013) Distinct phases of blood gene expression pattern through tuberculosis treatment reflect modulation of the humoral immune response. J Infect Dis 207(1): 18-29.

58. Mvubu NE, Pillay B, Gamieldien J, Bishai W, Pillay M (2016) Mycobacterium tuberculosis strains exhibit differential and strainspecific molecular signatures in pulmonary epithelial cells. Dev Comp Immunol 65: 321-329.

\section{Your next submission with Juniper Publishers} will reach you the below assets

- Quality Editorial service

- Swift Peer Review

- Reprints availability

- E-prints Service

- Manuscript Podcast for convenient understanding

- Global attainment for your research

- Manuscript accessibility in different formats ( Pdf, E-pub, Full Text, Audio)

- Unceasing customer service

Track the below URL for one-step submission https://juniperpublishers.com/online-submission.php 